\title{
Soft skills and universal competencies: relationship of concepts, structure and assessment
}

\author{
Yulia Borisovna Drobotenko ${ }^{1}$, Natalya Aleksandrovna Nazarova, Irina Leonidovna \\ Smagina, and Ekaterina Vladimirovna Panasenko \\ Omsk State Pedagogical University, Department of Foreign Languages (interfaculty), Omsk, Russia
}

\begin{abstract}
The task of a modern higher education institution is to form graduates' competencies that contribute to the construction of a flexible professional path in today's continuously changing society. Success in solving these problems is provided by the presence of university graduates of the so-called universal competencies (according to FSES 3++), reflected in the ability to think systematically, critically assess the situation and possible resources for solving the problem, the ability to cooperate and self-organize. In foreign educational practice, these competencies are known as "flexible" competencies or "soft" skills. The article aims to disclose the concepts of "soft skills" and "universal competencies" in a meaningful way, to correlate their structures and summarize the experience of soft skills and universal competencies assessment in Russian and foreign practice. Research methods include: theoretical analysis on different approaches to the interpretation of the concepts of "soft skills" and "universal competence"; structural-content and comparative analyses that allow us to identify the common and special in the content and structure of these concepts; summarizing the experience of assessing "soft" skills and universal competencies, which provides an opportunity to identify best practices for diagnosing these skills and competencies. The result of the study is seen in the presentation of tools for assessing the universal competence of university students and the development of recommendations for its application in practice. It is concluded that it is necessary to organize procedures for diagnosing the development of universal competencies of students at different stages of learning in higher education. The scientific novelty of the study is to enrich the ideas of the competence approach with the knowledge of the general and specific in the content and structure of "soft" skills and universal competencies, the peculiarities of their evaluation. Practical significance is seen in the possibility of using the materials of the article for further research; study the dynamics of the development of universal competencies; development of training materials for students of professional development courses.
\end{abstract}

${ }^{1 *}$ Corresponding author: $\underline{\text { drobotenko@omgpu.ru }}$ 
Keywords: soft skills, universal competencies, competency assessment, case testing

\section{Introduction}

The idea of broad humanitarian training, based on the principles of universality, began to actively replicate at the turn of the century, which was associated with changes in society, its transition to the stage of "informational", "post-industrial". The new conditions of society's development have transformed the concept of profession and professionalism, influencing the construction of a professional path, which has become multivariate and situationally conditioned. The structure of labor has become more complex, requiring from modern professionals the willingness not only to continuously improve narrow professional knowledge and skills, but also the ability to modernize their professional activities, namely to develop business communication skills; self-management which is the distribution of time and resources when solving professional tasks; organization of self-learning; application of the systematic approach to situation and problem assessment, etc. [1]. The Federal State Educational Standards of Higher Education (FSES HE 3++), coupled with professional standards, established the requirement to provide university training on the principles of universality and defined eight groups of universal competencies (UC), which should be formed in university graduates at all levels of education and for all directions and specialties. In the scientific literature, there are also debates about the significance of UC for future specialists [2-4]. Kazakova and Tarkhanova emphasize that the universality of training in higher education is manifested in the formation of socially and personally significant qualities, which are not necessarily related to a specific profession [5]. There are a number of works devoted to the comparison of the concepts of "universal competence" and "soft skills" [6]. The concept of "soft skills" is more common abroad (in the documents of the Council of Europe, UNESCO, etc.), although it is actively borrowed today by the domestic teaching community and the public when discussing the requirements for the results of university training and professional activity in general [6-7]. This article actualizes the problem that involves finding an answer to the question of what is the experience of forming and evaluating universal competencies and "soft" skills in Russian and foreign practice, which allows judging the success of training in the university. This requires understanding what is the meaningful and structural relationship between the concepts of "soft skills" and "universal competencies" and what assessment tools allow to record the dynamics of their development?

\section{Methods}

The methodological basis of the study: 1) philosophical categories of universality, from the perspective of which the results of training in the university can be viewed through the prism of uniformity; 2) the provisions of the competence approach used to comprehend the content, structure, and features of assessing the universal competencies of future specialists. The method of theoretical analysis used is aimed at exploring different approaches to the interpretation of the concepts of "soft skills" and "universal competencies"; methods of structural and content and comparative analysis are used to determine the common and special in the content and structure of these concepts; the method of generalizing experience in assessing "soft" skills and universal competencies provides an opportunity to identify the features of their diagnosis. 


\section{$3 \quad$ Results and discussion}

The term "soft skills" came into the Russian language at the beginning of the 21 st century and was used in the business sphere to define skills for working with people. These are complex integrated constructs that include: the techniques of critical thinking, creativity, cooperation; reflection and self-regulation techniques; the formation of certain character traits, expressed in the consciousness of choice, willingness to take responsibility [7]. Today there are a large number of classifications of "soft skills". The most popular is the taxonomy proposed by the Italian researcher [8]. The first group of soft skills (personal skills) can be called basic. They are formed due to certain traits of a person's character or are purposefully brought up. The possession of these skills ensures a responsible attitude of the specialist to solving certain professional tasks. The second group of soft skills (social) in most cases is acquired in the process of education, in communication with colleagues; it brings a person to an advanced level of professionalism and provides specialist confidence in dealing with certain responsibilities. The third group of soft skills (methodological) facilitates the specialist's search for non-standard solutions, improvement of practice, and exploration of new opportunities. These skills form a proactive stance and help achieve a breakthrough level of professionalism in any activity. Solving the problem of correlation of the concepts "soft skills" and "universal competencies", we came to the conclusion that "soft skills" are part of the structure of universal competencies (Table 1).

Table 1. Correlation of universal competencies and soft skills.

\begin{tabular}{|c|c|}
\hline Universal competencies & Soft skills \\
\hline $\begin{array}{l}\text { UC-1. able to search, critically analyze } \\
\text { and synthesize information, apply a } \\
\text { systematic approach to solve problems }\end{array}$ & $\begin{array}{c}\text { Thinking skills of the highest order: } \\
\text { - } \quad \text { research skills } \\
\text { - } \quad \text { analytical skills } \\
\text { creativity, innovativeness } \\
\text { information management skills }\end{array}$ \\
\hline $\begin{array}{l}\text { UC-2. able to determine the range of } \\
\text { tasks within the set goal and choose the } \\
\text { best ways to solve them on the basis of } \\
\text { the current legal norms, available } \\
\text { resources and limitations }\end{array}$ & $\begin{array}{l}\text { Goal orientation: } \\
\qquad \quad \text { managerial skills } \\
\bullet \quad \text { decision-making ability } \\
\bullet \quad \text { adaptability to change }\end{array}$ \\
\hline $\begin{array}{l}\text { UC-3. able to carry out social interaction } \\
\text { and fulfill their role in the team }\end{array}$ & $\begin{array}{cl}\text { Social } & \text { interaction skills: } \\
\bullet & \text { leadership skills } \\
\bullet & \text { group, team } \\
\bullet & \text { network administration } \\
- & \text { stress management }\end{array}$ \\
\hline $\begin{array}{l}\text { UC-4. able to communicate orally and in } \\
\text { writing in the state language of the } \\
\text { Russian Federation and foreign } \\
\text { language(s) }\end{array}$ & $\begin{array}{l}\text { Communication skills: } \\
\bullet \quad \text { negotiating } \\
\bullet \quad \text { negotiating skills }\end{array}$ \\
\hline $\begin{array}{l}\text { UC-5. able to perceive the cultural } \\
\text { diversity of society in socio-historical, } \\
\text { ethical, and philosophical contexts }\end{array}$ & $\begin{array}{l}\text { Social interaction skills: } \\
\text { - } \quad \text { adherence to professional ethics } \\
\text { cultural adaptability } \\
\text { - } \quad \text { orientation } \\
\text { management skills }\end{array}$ \\
\hline $\begin{array}{l}\text { UC-6. able to manage their time, build } \\
\text { and implement a trajectory of }\end{array}$ & $\begin{array}{l}\text { Self-control (self-management), } \\
\text { goal orientation: }\end{array}$ \\
\hline
\end{tabular}




\begin{tabular}{|l|ll|}
\hline $\begin{array}{l}\text { self-development based on the principles } \\
\text { of lifelong learning }\end{array}$ & $\bullet$ & self-development, self-awareness \\
& skills & \\
& $\bullet$ & learning skills \\
& $\bullet$ & responsibility \\
\hline
\end{tabular}

"Soft skills" is a connecting (cross-cutting) element of knowledge and skills (including professional) that make up the structure of universal competence (Figure 1). The formation of universal competencies is provided by "soft skills", which contribute to the holistic development of personality in educational and professional activities and allow manifesting universal qualities of personality in different contexts of today's unstable reality [9]. Surveys of employers confirm the value of these skills $[10,11]$.

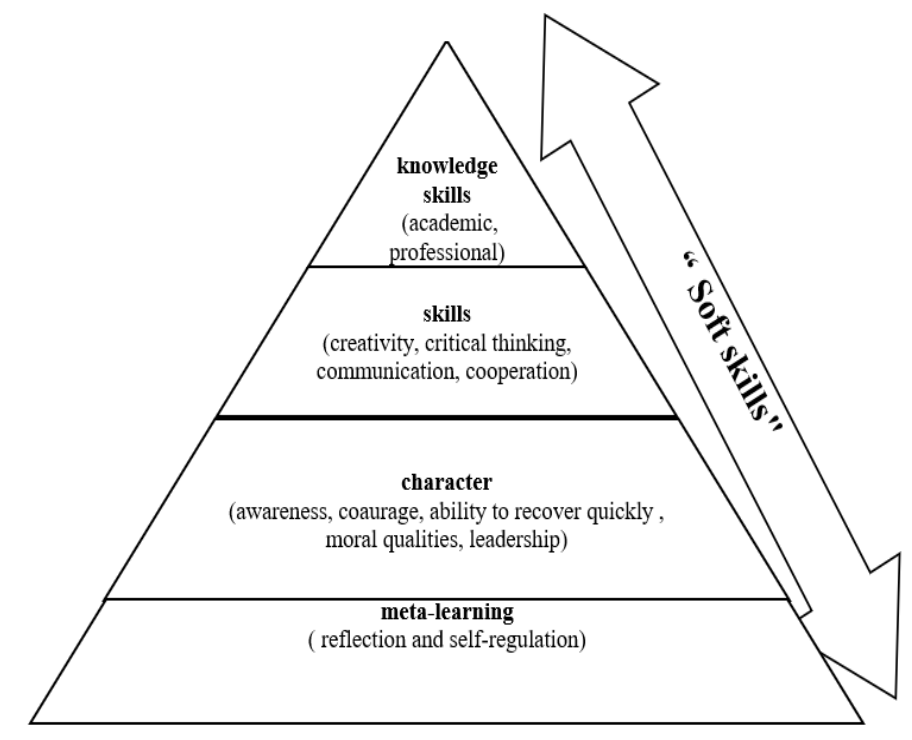

Fig. 1. "Soft skills" in the structure of universal competence.

The effective formation of universal competencies in the educational process of higher education requires reliable and valid assessment tools [12].

The competencies under study are hierarchical and integrative in their structure, and their assessment tools must be comprehensive and designed on an interdisciplinary basis [13, 14]. In developing the assessment toolkit, the following should be taken into account: 1) the $\mathrm{UC}$ are formed due to their systematic integration into a holistic educational process through content, technology and environmental factors [15]; 2) assessment of "soft skills", which are part of the structure of universal competencies, should take place in conjunction with the assessment of narrow professional "hard skills".

The assessment toolkit includes invariant and variable parts, which vary depending on the type of universal competence and the stage of higher education. Each assessed construct is decomposed into separate components [16] and appropriate assessment tools are selected for its assessment (Table 2).

Table 2. Means of assessing UC at different stages of higher education.

\begin{tabular}{|c|c|c|}
\hline $\begin{array}{c}\text { Stages of } \\
\text { training }\end{array}$ & $\begin{array}{c}\text { Objects of evaluation } \\
\text { (UC structure) }\end{array}$ & Assessment tools \\
\hline
\end{tabular}




\begin{tabular}{|c|l|l|}
\hline Initial & $\begin{array}{l}\text { Personal and social "soft skills", which are } \\
\text { dominated by academic knowledge and } \\
\text { automated skills }\end{array}$ & $\begin{array}{l}\text { testing, quizzes, individual and } \\
\text { group assignments, case studies, } \\
\text { discussions, interviews, survey }\end{array}$ \\
\hline Middle & $\begin{array}{l}\text { personal, social + methodological "soft skills", } \\
\text { including academic knowledge + professional } \\
\text { knowledge; skills and abilities; meta-skills }\end{array}$ & $\begin{array}{l}\text { testing, dialog technologies, } \\
\text { solving educational and } \\
\text { professional problems, games, } \\
\text { evaluation cases, projects, } \\
\text { simulations }\end{array}$ \\
\hline Final & $\begin{array}{l}\text { methodological, social and personal "soft } \\
\text { skills", the structure of which is dominated by } \\
\text { professional knowledge that allows him to act } \\
\text { in non-standard situations of educational and } \\
\text { professional activity, meta-skills; + "hard skills" }\end{array}$ & \\
\hline
\end{tabular}

\section{Conclusion}

The study of various assessment tools and diagnostic instruments shows that in order to obtain an objective assessment of UC formation (and the "soft skills" included in them) the most acceptable is the case-testing method. Case testing is an assignment that integrates knowledge-based assessment tools and problem situations. A case test tests a specific "portion of functionality" within a competency [17-18]. When solving case tests, the student must use concepts and methods from different disciplines, transfer technologies from a mastered field to a new field, build models, draw conclusions, and evaluate their adequacy (i.e., use mastered "soft skills"). Case tests most often simulate real-life domestic and professional situations and work on such cases allows putting the student in a state of intellectual tension, causing the need to solve a practical problem.

The research was carried out within the framework of the Omsk State Pedagogical University Science Development Foundation.

\section{References}

1. S.I. Osipova, N.V. Gafurova, E.A. Rudnitsky, Persp. Sci. Edu. 4(40), 91-101 (2019). https://doi.org/10.32744/pse.2019.4.8

2. A.S. Frolikova, N.A. Tereshchenko, M.K. Astafieva, Europ. J. Contemp. Edu. 9(1), 29-42 (2020). https://doi.org/10.13187/ejced.2020.1.29

3. M.M. Malova, Bul. Samara State Tech. Univ. Ser.: Psy. Pedag. Sci. 4(44), 150-165 (2019)

4. A.P. Mansurova, Bul. Moscow State Univ. Cult. Arts 5(61), 161-167 (2014)

5. E.I. Kazakova, I.Yu. Tarkhanova, Yaroslavsky Pedag. Newsl 5, 127-135 (2018)

6. J. Voogt, N. Roblin, 21st century skills: discussion paper (University of Twente Netherlands, Enschede, 2010)

7. M.A. Shemanaeva, Higher Edu. Rus. 8-9, 89-95 (2018)

8. F.M. Rasheed, N.A. Jurdi, J. Law, Pol. Glob. 89, 38-43 (2019). https://doi.org/10.7176/JLPG

9. Ch. Succi, Sociologia Del Lavoro, 137, 244-256 (2015). https://doi.org/10.3280/SL2015-137015

10. R. Lavi, M. Tal, Y.J. Dori, Stud. Edu. Eval. 70, 1-11 (2021).

https://doi.org/10.1016/j.stueduc.2021.101002 
11. S.V. Saltanova, Chto rabotodateli zhdut ot vypusknikov vuzov [What employers expect from university graduates]. Accessed on: July 22, 2021. [Online]. Available: https://issek.hse.ru/news/188206729.html

12. M. Gruzdev, E. Kasakova, I. Kuznetsova, I. Tarkhanova, Europ. J. Contemp. Edu. 7(4), 690-698 (2018)

13. Y.G. Yudina, V.G. Vasiliev, Psy. Sci. Edu. 24(1), 69-79 (2019)

14. E.I. Kazakova, I.Yu. Tarkhanova, Pedagogy, 9, 79-83 (2018)

15. O.B. Yarosh, I.F. Zinoviev, Edu. Self-Devel. 16(1), 116-128 (2021)

16. T.V. Bugaychuk, et al., Yaroslavsky Pedag. Newsl. 1, 131-135 (2016)

17. E.I. Perikova, A.E. Loviagina, V.M. Bysova, Sci. Edu. Today 9(4), 19-35 (2019)

18. A.Yu. Prosekov, I.S. Morozova, Z.V. Kretsan, Europ. J. Contemp. Edu. 10(1), 103-112 (2021). https://doi.org/10.13187/ejced.2021.1.103 